\title{
A micro scale study of climate change adaptation and disaster risk reduction in coastal urban strategic planning for the Jakarta
}

\author{
Harkunti Pertiwi Rahayu
}

School of Architecture, Planning and Policy Development, Bandung Institute of Technology, Bandung, Indonesia

Richard Haigh and Dilanthi Amaratunga

Global Disaster Resilience Centre, Huddersfield, UK, and

\author{
Benedictus Kombaitan, Devina Khoirunnisa and Vito Pradana \\ School of Architecture, Planning and Policy Development, \\ Bandung Institute of Technology, Bandung, Indonesia
}

\begin{abstract}
Purpose - This paper aims to describe an in-depth study that aimed to assess and develop a strategic disaster risk reduction plan to integrate climate change adaptation countermeasures in Cilincing, a North Jakarta City sub-district.

Design/methodology/approach - The study used a back-casting approach to cover hazard assessment induced by increased susceptibility, as well as vulnerability, both as a baseline study and projected up to 2045 at the micro level. The urban village (Kelurahan) level is the unit of analysis. The capacity analysis is used as baseline data, which is reviewed against the trend of the hazard and vulnerability.
\end{abstract}

Findings - The results of the study identify short-, medium- and long-term recommendations to integrate disaster risk reduction and climate change adaption. These include capacity building, especially emergency response capabilities, an increase of drainage capacity, improvements to transboundary management and minimising driving forces.

Practical implications - These findings at the micro level are very important to present a more holistic and realistic strategy that can be implemented until 2045, but also provides a basis for up scaling into metropolitan region planning.

(C) Harkunti Pertiwi Rahayu, Richard Haigh, Dilanthi Amaratunga, Benedictus Kombaitan, Devina Khoirunnisa and Vito Pradana. Published by Emerald Publishing Limited. This article is published under the Creative Commons Attribution (CC BY 4.0) licence. Anyone may reproduce, distribute, translate and create derivative works of this article (for both commercial and noncommercial purposes), subject to full attribution to the original publication and authors. The full terms of this licence may be seen at http://creativecommons.org/licences/by/4.0/legalcode

The results presented in this paper are a part of the research "Mainstreaming Integrated Disaster Risk Reduction and Climate Change Adaption Strategies into Coastal Urban Agglomeration", funded jointly by Newton Fund Institutional Link and Ristek Dikti for the year 2017-2018. This work was also supported by the Natural Environment Research Council [grant number NE/S003282/1].

Received 4 August 2018 Revised 21 August 2018 Accepted 25 October 2019 
IJDRBE 11,1

Originality/value - This is a unique, micro-scale case study in the Cilincing sub-district of Jakarta that assesses and develops strategic disaster risk countermeasures and a reduction plan that integrates the effects of climate change, thereby addressing future disaster risk in Jakarta.

Keywords Indonesia, Jakarta, Back-casting approach, Flood risk management, Land-use change, Socio-economic change

Paper type Research paper

\section{Background}

Creating a resilient society is a normative topic; some scientists have even described it as a utopia (Frommer, 2013). However, the point at which a society can be considered as resilient has not been clearly defined (Béné et al., 2012). Cities are facing long-term issues with complex underlying causes. It is now increasingly recognised that these problems are too difficult to solve using conventional planning approaches.

Back-casting is suitable for complex normative problems that require transformation changes such as sustainability and resilience (Dreborg, 1996). The approach integrates a comprehensive look over relevant studies, innovations and institutional transformation (Bibri, 2018).

Jakarta is a metropolitan city with a long history of flooding. Since the 2000 s, flood has been an annual reoccurring problem in many communities in Jakarta (Burch et al., 2010). This problem has developed into a very broad and complex problem, involving multiple sectors and stakeholders (Rahayu and Nasu, 2010).

As a result of environmental changes, such as climate change and land subsidence, as well as dynamic socio-economic changes in the future, it is estimated that the threat of flooding will be greater than currently faced (Ward et al., 2011; Field et al., 2014). Current policy efforts are estimated to be insufficient to overcome future flood hazards and will create gaps. These gaps are between the content of existing disaster management policies and spatial plans in the Cilincing District. These policies and spatial plans have not been able to meet the increasing levels of disaster risk. This gap must be addressed with adjustments to existing policies and new disaster management strategies that can better address emerging and future needs.

\section{Scope of problem}

To have a comprehensive look at the problem, a flood crunch and release model has been developed. The model can aid in identifying root problems and driving forces to the increased future flood risk in Jakarta. As a result, spatial and development planning may be able to target more precisely these specific components and, in the long-term, solve the issue. Rahayu and Nasu (Rahayu and Nasu, 2010) defined underlying causes and problems that contribute to the increase in flood magnitude in Jakarta, as shown in Figure 1, in addition to the vicious cycle of flood impact to the underlying problems.

Three main issues were identified as the main underlying problems that are contributing to the long-term flood risk issue in Jakarta. These are: climate change, uncontrolled urbanisation and development and weak socio-economic governance. As stated in Roth and Warner (2007), in flood-prone regions, "water" may require a specific land-use category, adding another competing interest over land in the planning process.

Climate change impacts on hydro-meteorological hazards, otherwise called climate hazards, are changing in terms of frequency, susceptibility and severity in the long period. Long-term planning needs to consider not only the current risk but also the projection of future risk. Learning from several studies done in this area, this study focuses on both scenarios, i.e. current and a 2040 scenario. 


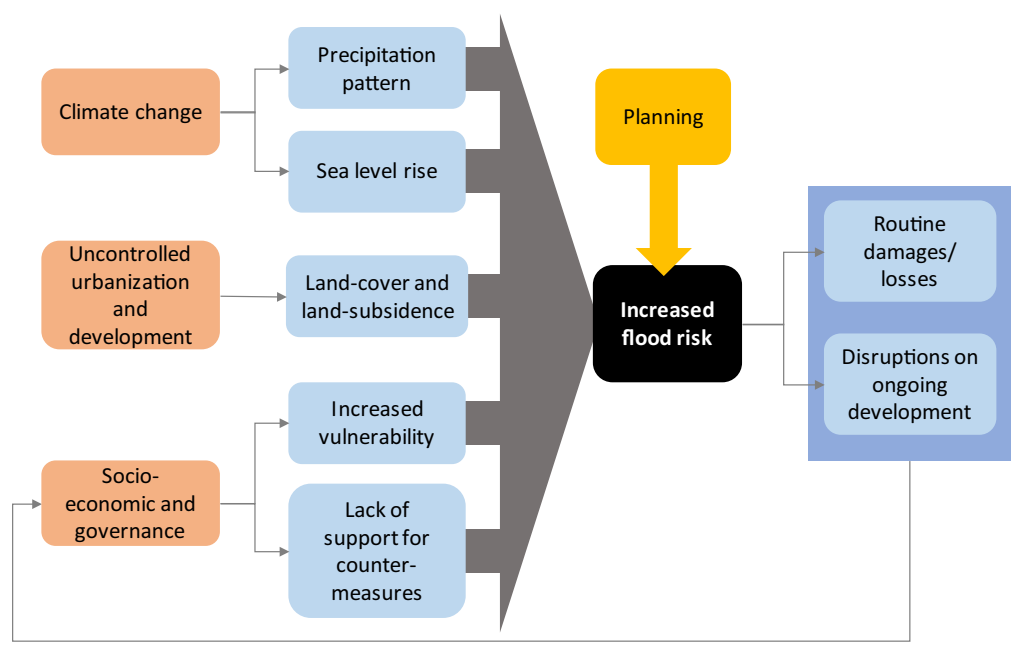

Source: Rahayu and Nasu (2010)
Coastal urban strategic planning

Figure 1. Jakarta flood risk model adapted from crunch and release model

\section{Purpose}

This paper describes a study to develop a sustainable strategy for flood disaster risk reduction in the Jakarta Metropolitan Area, with the goal of addressing the current and projected flood risk up to 2040. It achieves this through a micro-scale case study in the Cilincing sub-district of Jakarta. The study attempts to assess and develop strategic disaster risk countermeasures and a reduction plan that integrates the effects of climate change, thereby addressing future disaster risk in Jakarta. The Cilincing sub-district, located in North Jakarta, was selected as a case study because of the mixture of households, business, manufacturing industries and port operations.

The three main objectives of this research are:

(1) to assess current and future flood risk using a 2040 projection in Jakarta that considers both in-land and sea flood hazard;

(2) to identify the existing climate change (CCA) and disaster risk reduction (DRR) countermeasures in Jakarta and the Cilincing sub-district; and

(3) to propose a set of recommendations on micro-scale CCA and DRR strategies to reduce future flood risk in Cilincing sub-district.

\section{Methodology}

The study adopts a semi-quantitative approach and uses a back-casting method to identify strategic flood risk reduction measures in the Jakarta region, Indonesia. The approach involves a quantitative future projection of flood risk assessment and qualitative interpretation of observations and interviews data. The analysis uses both primary and secondary data.

Primary data were collected mainly using two methods: visual observation and interviews. Interviews were conducted with stakeholders in the Cilincing sub-district responsible for and affected by the flood risk, including government, community members and industries. Government institutions' respondents were from the DKI Jakarta Disaster 
IJDRBE 11,1

Management Office and Cilincing sub-district office. Community members of Cilincing subdistrict were represented by the Rukun Warga $(R W)$ chiefs in the affected Rukun Wargas $(R W s)$, and industries were represented by PT. Kawasan Berikat Nusantara $(\mathrm{KBN})$ dan PT Karya Citra Nusantara (Marunda Port operator). Observations data included the river condition and flood infrastructure in Cilincing sub-district, including dykes, drainage, pump houses/flood gates and evacuation equipment.

Secondary data, including spatial maps and statistical data, were obtained from institutions responsible for that data, as well as formal documents available for open access. Formal documents included the Cilincing sub-district in numbers 2017, Jakarta Special Region Disaster Countermeasure Plan 2014-2019, urban village demographic data, Cilincing sub-district land prices and geographic/spatial map data.

\subsection{Analytical methods}

Analysis in this study includes several components, namely, a projected flood risk assessment in 2040, using the analytical hierarchy process (AHP) to assess risk index levels and linear projection analysis. AHP is an expert judgement measurement method using pair-wise comparison of the different components to define the priority scale of each components in the hazard, vulnerability and capacity in a risk assessment. The linear projection analysis, otherwise known as arithmetic projection, is used to project the population number as one of the vulnerability factors. The projection analysis method has been selected based on the smallest standard deviation, which is the linear projection method.

Risk assessments are conducted independently in each RW in the Cilincing sub-district. The risk index measurement follows the projected risk analysis formula:

$$
R_{P}=\frac{H_{P} x V_{P}}{C}
$$

where:

$$
\begin{aligned}
& R_{P}=\text { denotes the projected risk index; } \\
& H_{P}=\text { denotes the projected hazard index; } \\
& V_{P}=\text { denotes the projected vulnerability index; and } \\
& C=\text { denotes the current capacity index. }
\end{aligned}
$$

Components in the projected risk analysis (projected hazard index, projected vulnerability index and current capacity index) are measured using the AHP. Each of the factors in the risk components (hazard, vulnerability and capacity) is classified into five index levels: very low, low, moderate, high and very high. The projected hazard index is measured using two variables: projected inundated area to total area ratio, which accounts to 75 per cent of the final score index, and projected collateral hazard probability (contamination, environmental degradation and infectious diseases), which accounts to 25 per cent of the final score index. The projected hazard index was measured using ArcGIS.

A flood model from a previous study by Afifah and Latief (2017) on Flood Hazard Assessment due to Sea Level Rise in North Jakarta in 2036-2040 is used in this analysis (Figure 2). The model considers both in-land flooding due to precipitation and sea flooding. The inundation model is broken down to each RW administrative boundary and divided by the total administrative area. The ratio of inundated area per total area in each RW is the final value used for index scoring.

The inundation model, as referred from Afifah and Latief (2017), follows the following formula:

$$
\text { Inundation }=S L R+H H W L+M S L \text { Variance }+L S+B+M J O+L N
$$




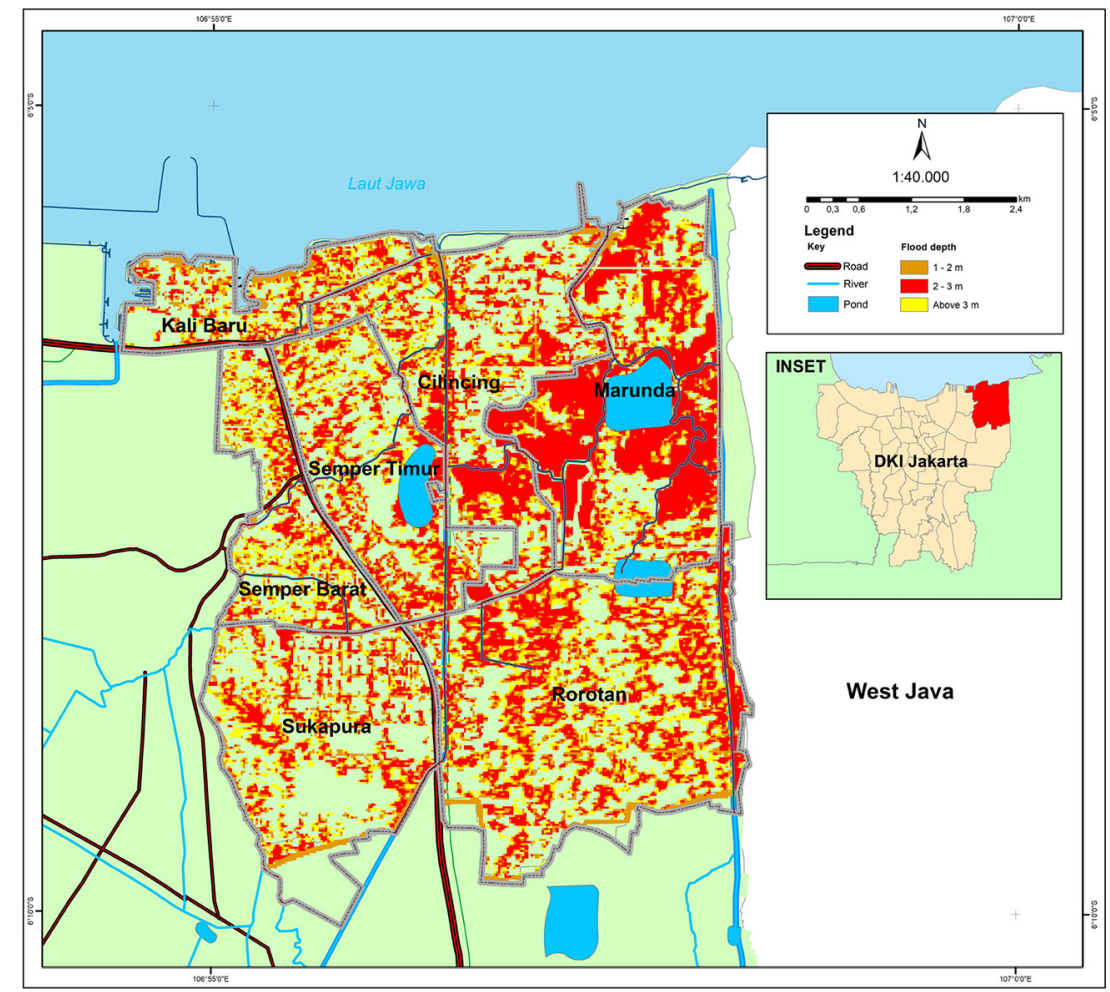

Coastal urban strategic planning

Figure 2.

Projected flood hazard map considering the sealevel rise due to climate change in Cilincing sub-district in 2036-2040 is developed based on the study of Afifah and Latief (2017)

where:

SLR = denotes the sea-level rise projection;

HHWL = denotes the highest high water level;

MSL Variance $=$ denotes the mean sea-level variance;

LS = denotes land subsidence;

$F \quad=$ denotes in-land flood;

MJO = denotes Madden-Julian oscillation; and

$L N \quad=$ denotes La-Nina.

The vulnerability index is measured through three components, namely, physical, social and economic vulnerability. The categorisation of these three components follows the three vulnerability factors, as presented in Haryanto (2011) on the identification of flood vulnerability factors in Central Jakarta. The weights of each vulnerability components are determined using AHP based on expert judgements from the interviews.

Meanwhile, for this study, measurement of capacity is based on the continuity of floodrelated programmes, the community involvement and programme success parameters. These components account to the capacity index, respectively by 20, 40 and 40 per cent. Table I shows a summary of vulnerability and capacity factors being considered in this analysis.

Back-casting is a planning method of visualising a common future vision or goals and using the gap between current condition and the future vision as the departing point for 


\section{IJDRBE 11,1}

124

Riverbank

Critical facilities

Social vulnerability

Projected population density

Education level

Poverty level

Vulnerable group

Economic vulnerability

Land value/price

Capacity

Programme continuity

Table I.

Community involvement

Vulnerability and Program success
Index parameter

Regions dominated by built environment will be higher in flood vulnerability

Regions with closer proximity to river or other types of water bodies have higher vulnerability

Regions that has more critical facility in terms of importance and scale of services have higher vulnerability

Higher population density leads to higher vulnerability

Population with lower education level leads to higher flood vulnerability

Regions with higher ratio of population below poverty line has higher vulnerability

Infants/toddlers, elder, and diffable population are more vulnerable to flood

Higher-priced land has higher vulnerability from flood

Existence of any flood-related programmes increases the capacity level Community involvement in flood-related programmes increases the capacity level

Programmes that show evidence of lowering hazard or vulnerability increases the capacity level

strategic planning (Vergragt and Quist, 2011). Back-casting future CCA and DRR strategies in this study is achieved by using a qualitative analysis to identify the gaps between the capacity in the current risk scenario, with a capacity need based on a projection of future risk. It should also consider possible changes which might influence direction of the issue in the future (Dreborg, 1996). Several studies have used a similar approach in environmental and urban issues and climate-disaster mitigation (van der Voorn et al., 2012; Gleeson, 2012).

\subsection{Micro-scale study case in Cilincing sub-district}

One of the most severe flood events in Jakarta took place in 2007, when numerous subdistricts in the northern part of Jakarta were flooded. Widespread flooding occurred in Cengkareng, Grogol Petamburan, Kembangan, Sawah Besar, Senen, Kemayoran, Penjaringan, Pademangan, Tanjung Priok, Koja, Kelapa Gading, Cilincing and Cakung subdistricts. Cilincing was a sub-district that experienced a large flood area, with almost half of it flooded, especially in the western part (west of Cakung Drain). The urban communities (kelurahan) that were affected by the flood were Rorotan, Sukapura, Semper Barat, Semper Timur and Cilincing. In the past five years, severe flooding occurred in these urban communities, and the highest flood occurred in Rorotan, which reached $180 \mathrm{~cm}$ of height and lasted for about day days.

These events have reaffirmed that Cilincing is at high risk of flooding. Despite frequent exposure and high flood risk, there have been few reported efforts to improve capacity in this sub-district. Without further intervention, Cilincing is likely to experience higher flood risk in the future and increasing losses from these events. 
Cilincing sub-district has seven jurisdictions of urban village called Kelurahan, i.e. the lowest level of administrative local government structure. For this study, the risk assessment is carried out at the level of $R W$ or sub-village, i.e. a cluster composed of several neighbourhood associations called Rukun Tetangga (RT), as shown in Table II. Each urban village in Cilincing sub-district consists of 10 to 17 RWs. In this study, the unit analysis for all risk components, except for capacity, are measured at the RW level. Meanwhile, the capacity index is measured at the urban village level. In the analysis, an ordinal risk index is assigned for each RW.

Cilincing sub-district has faced a rapid urbanisation in the past. The population density in this sub-district has almost doubled in 25 years, from 5.581 person $/ \mathrm{km}^{2}$ in 1990 up to 9.628 person $/ \mathrm{km}^{2}$. The rapid increase in population occurred more specifically in Sukapura, Marunda and Kalibaru urban villages, where a lot of jobs have been created in local industries, warehouses and the port area.

The main land use in Cilincing sub-district are residential, industries, warehouses, offices and commercial. Although most of the west part of Cilincing sub-district has been developed with buildings to support industrial activity and for residential use, a lot of land in the eastern part remains undeveloped or used for agriculture, for example, in the form of rice paddies, green open space and flood retention polder (ponds). Industrial land use is the second dominant land use after residential in west Cilincing sub-district. This is because there is PT. Kawasan Berikat Nasional (PT. KBN), an integrated industrial zone which is located in Cilincing, Marunda and Sukapura urban communities.

Compared to some other regions in Jakarta Metropolitan Area, Cilincing sub-district has a relatively lower elevation due to land subsidence, ranging from -2 to 6 meter above sea level (Google Earth, 2018). Interestingly, some areas located away from the coastal area, specifically in Sukapura and Marunda, have lower elevation than the coastal line. This results in inland floods still being an inherent problem, besides the increasing risk of coastal floods.

There are four main flood-susceptible rivers in Cilincing sub-district. These are Kali Cakung Lama, Cakung Drain, Kali Blencong and Sungai Tiram. However, there has been a relatively new water structure, namely, East Canal Flood (Banjir Kanal Timur), which has increased the structural capacity of the sub-district.

\section{Results}

\subsection{Projected hazard and vulnerability assessment in Cilincing sub-district}

There are two main driving forces of flood in Jakarta: the inland flooding and coastal flooding. Inland flooding is caused by rainfall intensity in a local area that was not anticipated when the available drainage system was developed. Meanwhile, coastal

\begin{tabular}{llc}
\hline No. & Urban villages & No. of RWs \\
\hline 1 & Sukapura & 11 \\
2 & Rorotan & 12 \\
3 & Marunda & 10 \\
4 & Cilincing[ $[1]$ & 10 \\
5 & Semper Timur & 11 \\
6 & Semper Barat & 17 \\
7 & Kalibaru & 15 \\
Total & & 86
\end{tabular}

Coastal urban strategic planning

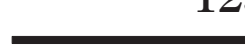


IJDRBE

11,1

126

flooding is due to a high sea-water level in the coastal area. If coastal flooding occurs at the same time as inland flooding, this was the potential to cause a backwater phenomenon, in which the flood water from the land cannot flow downstream. This can significantly increase the severity of flooding inland and in the coastal area (Asdak et al., 2018). In this study, it is important to consider coastal flooding because sea-level rise due to climate change is expected to aggravate this impact (Afifah and Latief, 2017).

Geographically, many places in Jakarta have lower elevations than the sea level. With increasing urbanisation in this metropolitan area, land subsidence has lowered the elevations in some regions during the past decade, which has increased flood vulnerability (Firman et al., 2011). This has caused recurring flooding during periods of high precipitations. Moreover, studies have found that climate change will have impacts on the precipitation cycle, both in terms of intensity and time (Budiyono et al., 2016). Rainfall is expected to occur during a shortened season period but with increased intensity, significantly increasing flood risk.

In 2040, the Cilincing sub-district is expected to be at a high threat from both inland flooding and coastal flooding. Due to the changes in coastal conditions, most adjacent areas and any areas surrounding water bodies are at even higher flood risk. The projected hazard index of Cilincing sub-district in 2040 is shown in Figure 3.

According to the vulnerability analysis, Cilincing sub-district has a relatively lower vulnerability to flood hazard that some other districts. This is due to the higher ratio of

Figure 3.

Cilincing sub-district projected hazard map for 2036-2040

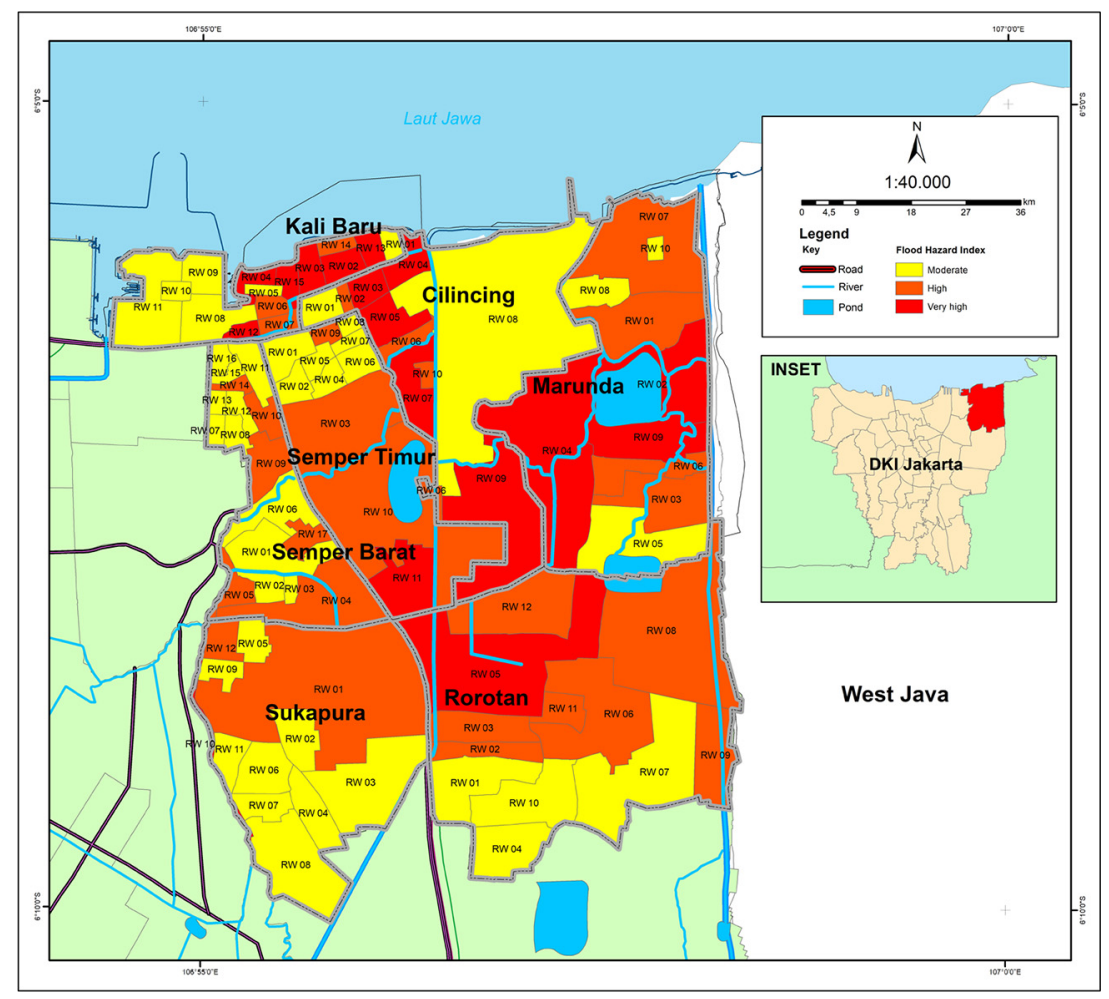


unbuilt open space in Cilincing sub-district when compared to other sub-districts in Jakarta. In 2040, most areas in the Cilincing sub-district are expected to have a low- to moderate-level vulnerability to flooding, but with some RWs in one of the urban villages (Kelurahan Kalibaru) expected to have a high-level vulnerability. This is shown in the projected vulnerability map in Figure 4.

The higher vulnerability level in some areas, as shown in Figure 4, is due to several factors. First, these areas are mainly covered by slums, increasing both their physical and economic vulnerability. Most of the houses are temporary buildings, which have poor

Coastal urban strategic planning resistance to flood water. In addition, there are many industries and warehouses in this part of Cilincing sub-district, with higher levels of economic exposure in Jalan Raya Cakung Cilincing and Jalan Raya Tipar Cakung.

\subsection{Existing flood disaster risk reduction countermeasures}

Efforts have been made by the Provincial Government of DKI Jakarta to reduce losses associated with flooding. These include integrating flood risk into the spatial development plans, the development of flood mitigation plans and capacity-building activities involving local government, NGOs and communities. This study attempts to evaluate the impact of such countermeasures. An in-depth investigation was conducted to assess the capacity level achieved through existing flood countermeasures. The capacity assessment will become a departing point to analyse and create future recommendations to meet the gaps between the present and future risk.

The capacity assessment in this study relies on primary and secondary data. Current flood countermeasures were surveyed through direct observation and interviews with RW chiefs in Cilincing sub-district.

Analysis of this data identified several significant countermeasures against flooding since the 2007 Jakarta floods. The Provincial Government has been emphasising mitigation efforts in five main aspects:

(1) construction of canal flood structures;

(2) river and drainage normalization;

(3) river and sea dykes;

(4) land use control in riverbanks; and

(5) pumps, watergates and solid waste filters.

Structural flood mitigation efforts such as the East Canal Flood and West Canal Flood have been put in place by the Provincial Government after the 2007 flood. Moreover, there have been initiations to build Cengkareng Drains I and II to add additional support for the West Canal Flood.

During the past 20 years, the increasing threat posed by coastal flooding has added to the complexity of Jakarta flood risk. In 2008 and 2009, several sea dyke structures were built across the region: Muara Angke, Muara Karang, Pluit Luar Batang, Cilincing, Marunda and Martadinata. These structures have an average length of 3,000 $\mathrm{m}$ and vary in height from 1 to $3 \mathrm{~m}$.

The drainage system in Jakarta uses a polder system in combination with a pump system, which are located mainly in the North Jakarta region, which has the lowest elevation level and is prone to coastal flooding. Polder relies heavily on artificial water bodies such as reservoirs, retention ponds and controlled watergates. Many flood pumps have been installed throughout Jakarta, and there are plans to install more in the future. However, the 
IJDRBE

11,1

128

Figure 4.

Cilincing sub-district projected vulnerability 2040

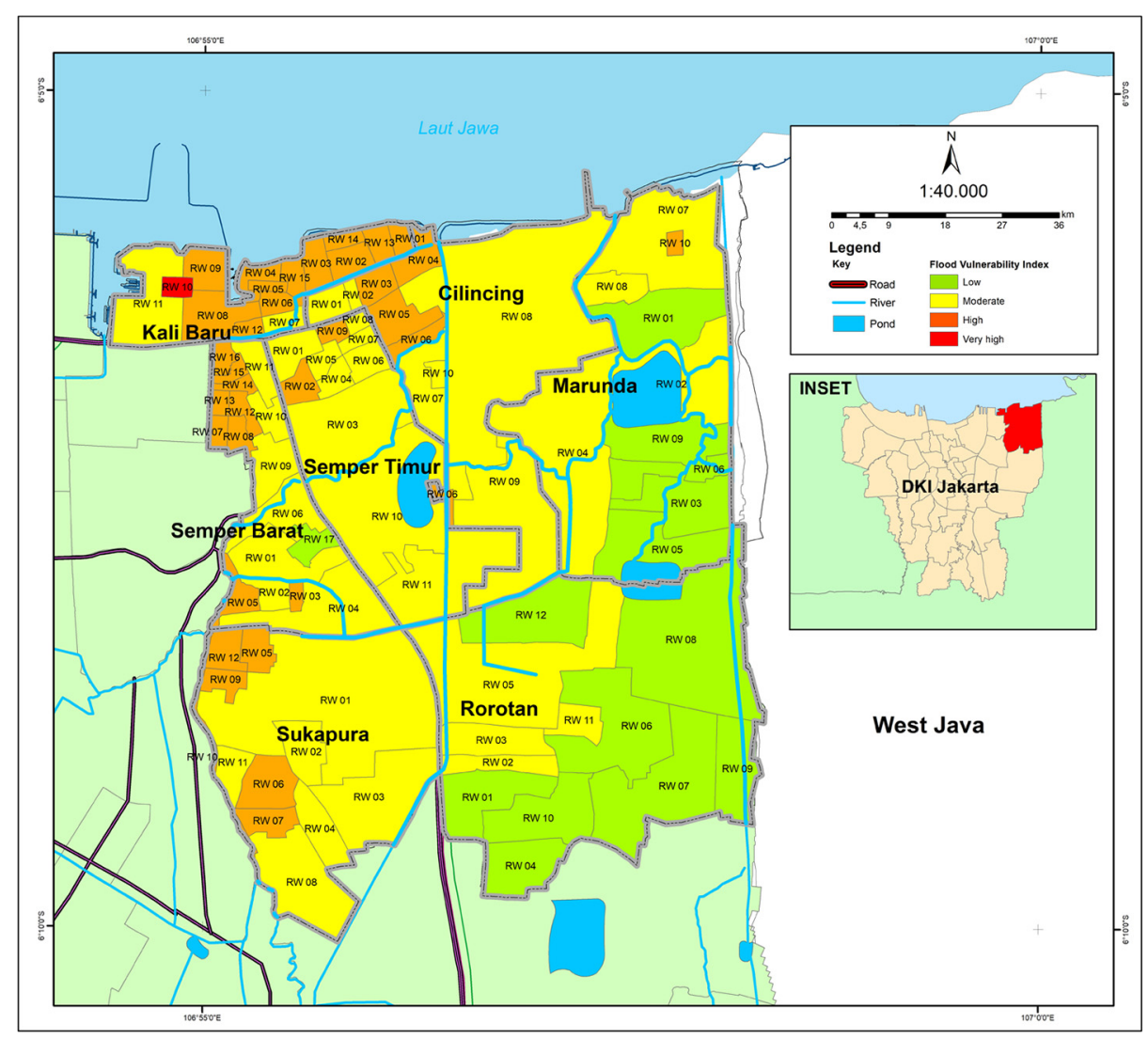

effectiveness of these measures is heavily dependent on the regulation of dams and watergates, which must be achieved through appropriate institutional arrangements and governance. The Indonesian context is challenging. Indonesia began a process of rapid government decentralisation in 1999 from a formerly strong centralised government structure. Prior to 1999, the state could enforce flood mitigation measures. Decentralisation has shifted authority to the local level. While this type of decentralisation is often associated with good governance and can bring many benefits, it has a tendency to create fragmentation and make coordination more complex. Each local government has the power to enact regulations, develop its own plans and programmes and decide on their own priorities based on local interests. It has also led to more institutions at different government levels, including national, provincial and local levels, including those responsible for flood management. The decentralised administrative structure in Indonesia is widely considered to have hindered its ability to achieve an integrated, basin-wide management arrangement.

Overall improvement in the drainage system capacity has been conducted at the provincial level in Jakarta. This is because of the success of Petugas Prasarana dan Sarana Umum (PPSU), otherwise known as "orange troops" and Dinas Sumber Daya Air (DSDA Department of Water Resource) DKI Jakarta otherwise known as "blue troops". Since the introduction of orange and blue troops as regular patrols, the volume of solid waste and mud 
contained in waterways or other water bodies in Jakarta has been significantly reduced. The success of this programme has increased the capacity to address flood risk because of improved drainage capacity (prevention), and more human resources to provide a faster response capacity.

Besides the capacity of the drainage system, government has also focused on the condition of floodplains, especially in close proximity to the rivers. Interventions include construction of concrete structures to strengthen the drainage system, broadening the common space in the riverbank, planting trees and clearing of illegal land uses in the river environment.

According to the capacity assessment result shown in Table III, Rorotan and Semper Barat are the two urban communities with the highest capacity index, followed by Cilincing and Semper Timur. The urban village which has the lowest capacity index in Cilincing subdistrict is Kalibaru. It is problematic because in 2040, the flood risk Kalibaru, which is bordered by the Jakarta Sea, will be significantly higher than in the present due to sea-level rise. Up to the time of the data collection in Kalibaru, there were no emergency response plans in place. Although flooding has occurred less frequently in Kalibaru than in some other communities, it is projected that Kalibaru will have more floods in 2040.

\subsection{Back-casting disaster risk reduction and climate change strategies for future flood risk in} Cilincing sub-district

According to the projected flood risk map, shown in Figure 5, the projected flood risk index in urban communities in Cilincing sub-district ranges from very high to low. Kalibaru community, which is located in the north-west part of Cilincing sub-district, has the highest flood risk in 2040 (very high).

Until recently, past floods have predominantly affected urban communities away from the immediate coastline and alongside the Ciliwung river basin. However, the projected hazard map for 2040 indicates that coastal areas will be more exposed in the future. This is due to an increased threat of coastal flooding, caused by sea-level rise and land subsidence. If high sea-water level occurs at the same time as inland flooding, this has the potential to cause a backwater phenomenon, in which the flood water from the land cannot flow downstream. Future flood countermeasures will have to address this emerging threat. Recent flood events tend to support this conclusion, as along with lower lying lands in Jakarta, communities located close to the coastal area have increasingly experienced flooding. The projected hazard maps for 2040 suggest this trend will continue.

The back-casting scenario visualised in this study is a normative scenario (van Vliet and Kok, 2015). A normative scenario refers to an ideal visualised future goal. In this study, the strategy recommendation is built upon a future aim in which flood risk in Cilincing subdistrict and Jakarta is minimised.

\begin{tabular}{llcc}
\hline No. & Urban villages & Capacity score & Capacity index \\
\hline 1 & Sukapura & 2.201301 & 2 \\
2 & Rorotan & 3.460989 & 4 \\
3 & Marunda & 2.077652 & 2 \\
4 & Cilincing & 3.377932 & 3 \\
5 & Semper Timur & 2.941759 & 3 \\
6 & Semper Barat & 3.42428 & 4 \\
7 & Kalibaru & 1.08761 & 1 \\
\hline
\end{tabular}

Coastal urban strategic planning

\section{$-2$}


IJDRBE

11,1

130

Figure 5.

Projected flood risk index in Cilincing sub-district in 2040

Figure 6.

Back-casting process
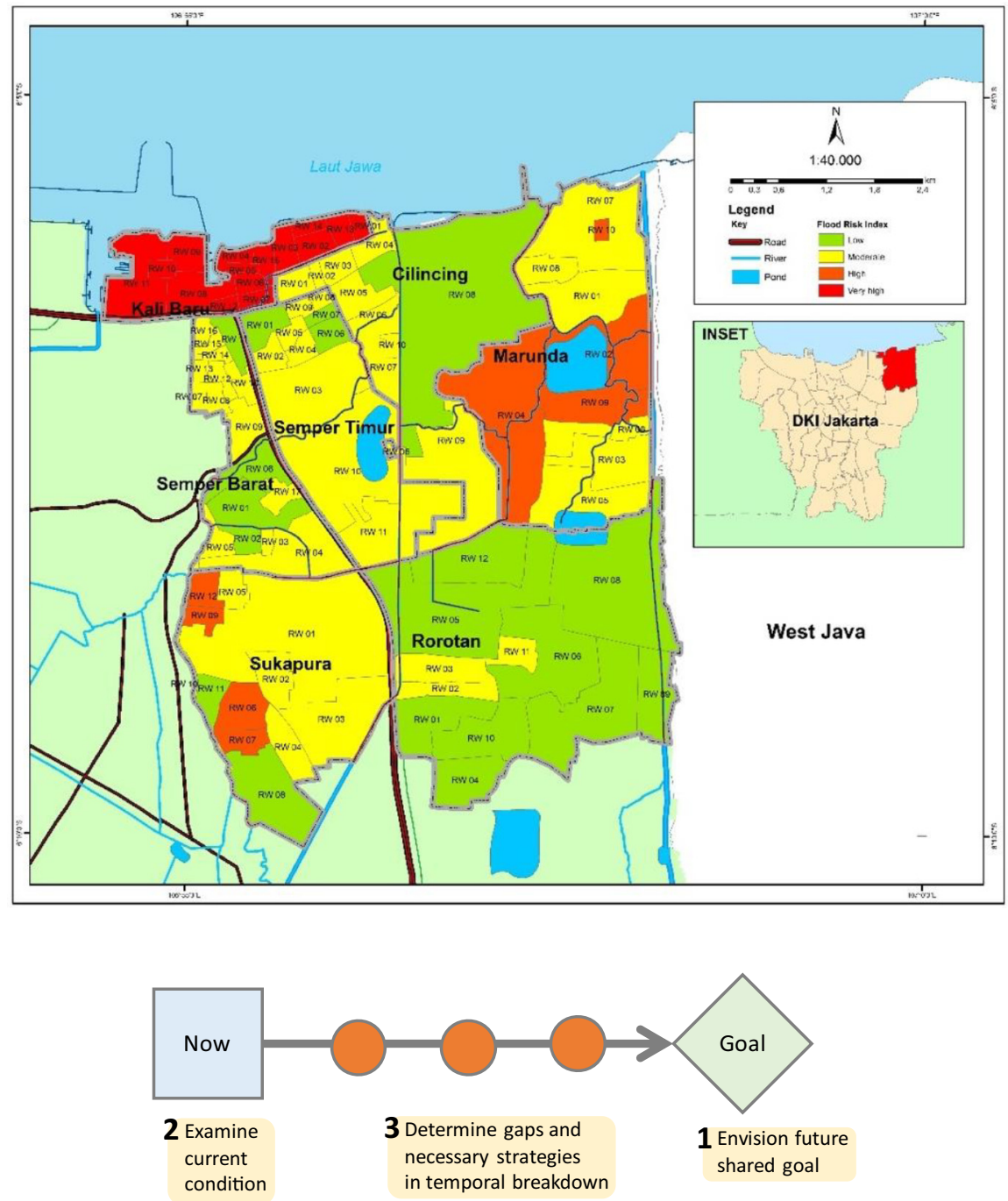

Source: Adopted from OECD (2013)

\section{Discussion and recommendations}

In this study, we propose a set of recommendations that are classified into three terms: short, middle, and long term.

6.1 Short term: capacity building, especially emergency response capabilities (flood EWS, quick recovery)

This risk assessment has exposed the lack of capacity in several urban communities, especially in Kalibaru community. Although this urban village not been highly exposed to 
previous flooding events in Jakarta, their exposure is expected to rapidly increase in the coming decades. To address this growing flood risk, it is will be necessary to grow the Kalibaru community's capacity. In the short term (1-5 years), the flood countermeasure strategy will need to address emergency response and recovery capabilities, including an integrated end-to-end flood early warning system, which is socially and legally accepted/ supported by the triple helix, i.e. government, community and private sectors.

\subsection{Middle term: Increase drainage capacity to meet future threats}

With climate change as one of the driving factors of flood, countermeasure efforts will have to accelerate to address future hazard levels. The drainage system in Jakarta is using the "polder" system, which refers to an artificial water drainage system where many water bodies might have higher surface levels than the land surrounding it. Despite being well maintained in the past, drainage capacity will need to be increased. This means that more structural mitigation efforts will be necessary. Flood control has traditionally focused on such structural measures, but modern flood management takes a broader perspective, including management and social aspects. It will be important for Jakarta to integrate these structural measures with non-structural measures.

\subsection{Improve transboundary river management}

The effectiveness of structural measures is also determined by appropriate institutional arrangements and governance. There is a need to examine how and why the current transboundary river management arrangements are mitigating or exacerbating flood hazard impacts in urban and peri-urban areas of the major river basins flowing into Jakarta, such as the Ciliwung River Basin (CRB). In recent decades, the Jakarta Metropolitan Area has undergone widespread development and led Indonesia's impressive economic growth. The CRB, with an area encompassing $347 \mathrm{~km}^{2}$, starts upstream at Tugu Puncak located between Bogor and Cianjur Regencies, but runs downstream into the Jakarta Bay area. There has been rapid development within the CRB because of the increasing rate of population in the JABODETABEK (Jakarta, Bogor, Tanggerang and Bekasi City) area. Effective, integrated river basin management needs to address the many different sectors in society that have an interest in the water system.

\subsection{Long term: Minimise driving forces of the flood hazard}

The long-term plan is to minimise preventable driving forces: sea-level rise and land subsidence. It will be important to go beyond the timeframe of this study and consider scenarios after 2040. To achieve this, it will be essential to consider the integration between CCA and DRR in climate hazards (Rahayu et al., 2018).

\section{Conclusion}

This study has found that solid waste is no longer the main issue contributing to flood risk in Jakarta. Interventions such as river revitalisation and the introduction of "orange and blue troops" have been successful in reducing the impact of solid waste on the health of the river. However, new threats have emerged. Backwater flood due to climate change has become a driving force for future flood risk, along with increasing levels of vulnerability. The capacities of communities need to be strengthened to cope with the increasing vulnerability from demographic and economic factors as well as hazard due to climate change impacts. This is especially so in coastal areas, some of which have not experienced widespread flooding in the past, but are likely to be highly exposed in the future. Mainstreaming flood 
IJDRBE 11,1

disaster risk reduction in short-, middle- and long-term spatial and developing plans should also be a priority to ensure that inappropriate development is not taking place in areas that are at increased exposure to flood risk.

Although this paper has offered several recommendations to address the flood problem in Jakarta and Cilincing sub-district in particular, it will be important that further, in-depth studies are carried out in communities that are shown to be at increased flood risk. Studies will need to address structural and non-structural measures, including appropriate instructional arrangements. It is necessary that this process is followed up by participatory approach involving related governmental institutions, not only in Jakarta Province, but also other regions in the Ciliwung river basin, community organisations and the private sector. A back-casting approach for planning requires multiple stakeholders to envision a shared future goal and move towards governance, lifestyle and institutional transformation in the long term (Quist and Vergragt, 2006; Quist et al., 2011).

\section{References}

Afifah, I.N. and Latief, H. (2017), "Kajian Bahaya akibat kenaikan muka air laut di jakarta utara (flood hazard assessment due to sea level rise in North Jakarta)", Institut Teknologi Bandung, Bandung.

Asdak, C., Supian, S. and Subiyanto (2018), "Watershed management strategies for flood mitigation: a case study of Jakarta's flooding", Extreme Weather and Climate Change, Vol. 21, pp. 117-122.

Béné, C., Wood, R.G., Newsham, A. and Davies, M. (2012), "Resilience: new utopia or new tyranny? Reflection about the potentials and limits of the concept of resilience in relation to vulnerability reduction programmes", IDS Working Papers, Vol. 2012 No. 405, pp. 1-61.

Bibri, S.E. (2018), "Backcasting in futures studies: a synthesized scholarly and planning approach to strategic smart sustainable city development”, European Journal of Futures Research, Vol. 6 No. 1.

Budiyono, Y., Aerts, J.C.J.H., Tollenaar, D. and Ward, P.J. (2016), "River flood risk in Jakarta under scenarios of future change", Natural Hazards and Earth System Sciences, Vol. 16 No. 3, pp. $757-774$.

Burch, S., Sheppard, S.R.J., Shaw, A. and Flanders, D. (2010), "Planning for climate change in a floodprone community: municipal barriers to policy action and the use of visualizations as decisionsupport tools: planning for climate change in a flood-prone community", Journal of Flood Risk Management, Vol. 3 No. 2, pp. 126-139.

Dreborg, K.H. (1996), "Essence of backcasting”, Futures, Vol. 28 No. 9, pp. 813-828.

Field, C.B. and Barros, V.R, and Intergovernmental Panel on Climate Change (2014), (Eds), Climate Change 2014: impacts, Adaptation, and Vulnerability: Working Group II Contribution to the Fifth Assessment Report of the Intergovernmental Panel on Climate Change, Cambridge University Press, New York, NY.

Firman, T., Surbakti, I.M., Idroes, I.C. and Simarmata, H.A. (2011), "Potential climate-change related vulnerabilities in Jakarta: challenges and current status", Habitat International, Vol. 35 No. 2, pp. 372-378.

Frommer, B. (2013), "Climate change and the resilient society: utopia or realistic option for German regions?", Natural Hazards, pp. 17.

Gleeson, T., Alley, W.M., Allen, D.M., Sophocleous, M.A., Zhou, Y., Taniguchi, M. and VanderSteen, J. (2012), "Towards sustainable groundwater use: setting long-term goals, backcasting, and managing adaptively", Ground Water, Vol. 50 No. 1, pp. 19-26.

Haryanto, H. (2011), "Identifikasi tingkat risiko bencana banjir sebagai masukan dalam perencanaan tataruang di kota jakarta pusat (flood risk assessment for spatial planning recommendation in Central Jakarta)", Institut Teknologi Bandung, Bandung. 
OECD (2013), "Risk and resilience: from good idea to good practice", Working Paper.

Quist, J. and Vergragt, P. (2006), "Past and future of backcasting: the shift to stakeholder participation and a proposal for a methodological framework", Futures, Vol. 38 No. 9, pp. 1027-1045.

Quist, J., Thissen, W. and Vergragt, P.J. (2011), “The impact and spin-off of participatory backcasting: from vision to niche", Technological Forecasting and Social Change, Vol. 78 No. 5, pp. 883-897.

Rahayu, H.P. and Nasu, S. (2010), "Good practices of enhancement early warning system for high populated cities - a case study for Jakarta flood", Security Operations Center (SOC) Management Software, Vol. 6 No. 1.

Rahayu, H., Haigh, R. and Amaratunga, D. (2018), "Strategic challenges in development planning for Denpasar city and the coastal urban agglomeration of Sarbagita", Procedia Engineering, Vol. 212, pp. 1347-1354.

Roth, D. and Warner, J. (2007), "Flood risk, uncertainty and changing river protection policy in The Netherlands: the case of calamity polders", Tijdschrift Voor Economische en Sociale Geografie, Vol. 98 No. 4, pp. 519-525.

van der Voorn, T., Pahl-Wostl, C. and Quist, J. (2012), "Combining backcasting and adaptive management for climate adaptation in coastal regions: a methodology and a South African case study", Futures, Vol. 44 No. 4, pp. 346-364.

van Vliet, M. and Kok, K. (2015), "Combining backcasting and exploratory scenarios to develop robust water strategies in face of uncertain futures", Mitigation and Adaptation Strategies for Global Change, Vol. 20 No. 1, pp. 43-74.

Vergragt, P.J. and Quist, J. (2011), "Backcasting for sustainability: introduction to the special issue", Technological Forecasting and Social Change, Vol. 78 No. 5, pp. 747-755.

Ward, P.J., Marfai, M.A., Yulianto, F., Hizbaron, D.R. and Aerts, J.C.J.H. (2011), "Coastal inundation and damage exposure estimation: a case study for Jakarta", Natural Hazards, Vol. 56 No. 3, pp. 899-916.

\section{Corresponding author}

Dilanthi Amaratunga can be contacted at: d.amaratunga@hud.ac.uk

For instructions on how to order reprints of this article, please visit our website: 